\title{
Analisis Kecenderungan Mengkonsumsi Marjinal dan Faktor-Faktor Yang Mempengaruhi Konsumsi Masyarakat Jawa Timur
}

\author{
Rohmaniyah dan Slamet Subari
}

\author{
Program Studi Agribisnis Fakultas Pertanian Universitas Trunojoyo Madura \\ Email.Rohmaniyah6@gmail.com dan s.subari01@gmail.com
}

\begin{abstract}
ABSTRAK
Tujuan dari penelitian ini adalah (1) mengetahui faktor ekonomi makro yang mempengaruhi konsumsi masyarakat Jawa Timur, (2) menganalisis kecenderungan mengkonsumsi marjinal, (3) membahas pola konsumsi masyarakat Jawa Timur.Metode regresi linier berganda digunakan untuk menjawab tujuan pertama, tujuan kedua dihitung dengan menggunakan rumus MPC, sedangkan tujuan ketiga dianalisis melalui tabel pengeluaran konsumsi.Hasil penelitian menunjukkan bahwa pendapatan dan tingkat suku bunga mempengaruhi konsumsi masyarakat Jawa timur dengan nilai koefisien masing-masing sebesar 0,827 dan 0,334. Hal ini menunjukkan bahwa apabila terjadi kenaikan pendapatan dan tingkat suku bunga sebesar 1\% maka konsumsi akan meningkat sebesar 0,827 dan 0,334. Nilai MPC Jawa Timur berkisar antara -0,004 - 0,57 dengan rata-rata sebesar 0,240 (24\%), hal ini berarti bahwa 24\% pendapatan penduduk Jawa Timur digunakan untuk konsumsi, sedangkan $76 \%$ sisanya digunakan untuk keperluan diuar konsumsi. Pola konsumsi masyarakat Jawa timur menunjukan pola yang konsumtif terhadap konsumsi non makanan dengan persentase sebesar $54,12 \%$.
\end{abstract}

Kata kunci: Jawa Timur, Konsumsi, MPC

Marginal Propensity To Consume Analysis And Factors That Influence The Consumtion Of East Java Society

\begin{abstract}
The purpose of this research is (1) to know the macro economic factors that influence the consumption of East Java society, (2) to analyze the marginal propensity to consume, (3) to discuss the consumption pattern of the East Java community. Multiple linear regression method is used to answer the first objective, the second objective is calculated using the MPC formula, while the third goal is analyzed through consumption expenditure table. The result of the research shows that income and interest rate influence the consumption of East Java society with coefficient value of 0,827 and 0,334 respectively. This shows that if there is increase of income and Interest rate of $1 \%$ then consumption will increase by 0.827 and 0.334 . The value of East Java MPC ranges from -0.004 - 0.57 to an average of 0.240 (24\%), this show that $24 \%$ of East Java's income is used for consumption, while the remaining $76 \%$ is used for consumption purposes. East Java community consumption pattern shows consumptive pattern to non food consumption with percentage equal to $54,12 \%$.
\end{abstract}

Keywords: East Java, Consumption, MPC

\section{PENDAHULUAN}

Pengeluaran konsumsi merupakan salah satu variabel dalam makro ekonomi yang memberikan kontribusi paling besar tehadap pendapatan domestik bruto (PDB), yaitu sebesar $60-70 \%$.Dalam analisis makro ekonomi, konsumsi dibedakan menjadi dua macam yaitu konsumsi rumah tangga dan konsumsi pemerintah.Jika pengeluaran konsumsi semua orang di dalam suatu negara dijumlahkan maka hasilnya adalah pengeluaran konsumsi masyarakat negara yang bersangkutan (Sukirno, 2002).
Data statistik Indonesia menjelaskan bahwa pengeluaran konsumsi rumah tangga masih tetap menjadi urutan pertama dalam penggunaan PDB Indonesia.Kurang lebih dua pertiga bagian PDB nasional adalah untuk pengeluaran konsumsi rumah tangga. Pada tahun 2012 kontribusi pengeluaran konsumsi rumah tangga Indonesia terhadap PDB sebesar $55,35 \%$, sementara pada tahun 2013 kontribusinya naik sedikit menjadi $55,74 \%$. Melihat besarnya kontribusi pengeluaran konsumsi rumah tangga terhadap PDB tersebut, maka dapat 
dikatakan bahwa konsumsi rumah tangga mempunyai pengaruh yang sangat strategis dalam menentukan fluktuasi kegiatan ekonomi dari satu waktu kewaktu.

Pengeluaran konsumsi erat kaitannya dengan besaran pendapatan yang diterima oleh individu, dimana pendapatan tersebut dialokasikan untuk dua hal yaitu untuk konsumsi dan menabung. Ketika individu mempunyai pendapatan yang minim dan tidak dapat mencukupi konsumsinya maka mereka akan berusaha menutupi ketidak cukupan tersebut dengan mengambil tabungan mereka. Sebaliknya jika terjadi peningkatan pendapatan individu, maka konsumsi akan mengalami peningkatan dimana besaran tambahan pendapatan akan memperlihatkan pola kecenderungan mengkonsumsi.

Perbandingan besarnya tambahan pengeluaran konsumsi terhadap tambahan pendapatan dapat disebut hasrat marjinal untuk mengkonsumsi (marginal propensity to consume atau MPC). Masyarakat yang tingkat kehidupan ekonominya relatif belum mapan, angka MPC mereka relatif besar, artinya sebagian besar tambahan pendapatan mereka dialokasikan untuk aktivitaskonsumsi. Hal sebaliknya berlaku bagi masyarakat yang kehidupan ekonominya relatif mapan.Hal ini konsisten jika ditarik dalam skala makro. Umumnya Negara-negara dengan tingkat perekonomian yang telah maju share PDB untuk belanja konsumsi rumah tangga relatif lebih kecil di bandingkan dengan Negara-negara yang tingkat perekonomiannya belum berkembang.

Provinsi Jawa Timur adalah salah satu provinsi yang mengalami fluktuasi kondisi perekonomiannya.Tabel 1 menyajikan pertumbuhan ekonomi Jawa Timur tahun dasar 2010.

Tabel 1. Kondisi Ekonomi Jawa Timur dan Nasional Tahun Dasar 2010

\begin{tabular}{cccc}
\hline Pertumbuhan Ekonomi & \multicolumn{3}{c}{ Tahun } \\
\cline { 2 - 4 } & 2013 & 2014 & 2015 \\
\hline Jawa Timur & 6,08 & 5,86 & 5,44 \\
Nasional & 5,78 & 5,02 & 4,79 \\
Kontribusi PDRB Jawa Timur terhadap & 14,99 & 14,16 & 14,36 \\
Nasional (\%) & &
\end{tabular}

Pertumbuhan ekonomi secara kumulatif Jawa Timur pada tahun 2015 mencapai 5,44 persen sedikit melambat bila dibandingkan dengan tahun 2014 yaitu sebesar 5,86 persen. Namun pertumbuhan ekonomi pada tahun 2015 lebih tinggi bila dibandingkan dengan pertumbuhan ekonomi Nasional $(4,79$ persen). Semakin tingginya pertumbuhan ekonomi suatu wilayah menunjukkan bahwa kesejahteraan masyarakatnya semakin membaik.

Produk Domestik Regional Bruto (PDRB) per kapita penduduk Jawa Timur setiap tahunnya mengalami peningkatan. Data statistik Jawa Timur tahun 2016 menjelaskan bahwa PDRB per kapita masyarakat Jawa Timur mencapai Rp. 36,04 juta pada tahun 2013, kemudian meningkat menjadi Rp. 39,90 juta di tahun 2014. Angka tersebut masih mengalami peningkatan kembali di tahun 2015 menjadi Rp. 43.50 juta.Hal tersebut menandakan bahwa setiap penduduk mempunyai kontribusi terhadap pertumbuhan ekonomi Jawa Timur sebesar Rp. 43.50.Peningkatan PDRB yang semakin tahun semakin tinggi menunjukkan bahwa perekonomian masyarakat Jawa Timur tumbuh dengan baik, bahkan angka tersebut lebih tinggi dari pada Nasional.Sehingga dapat dikatakan bahwa secara umum tingkat kesejahteraan masyarakat Jawa Timur semakin membaik seiring dengan meningkatnya PDRB.

Pendapatan merupakan faktor terpenting dari konsumsi. Teori yang di kemukakan oleh Keynes yang disebut dengan absolute income hypothesis menyatakan bahwa apabila pendapatan mengalami kenaikan maka konsumsi masyarakat juga akan mengalami kenaikan (Naga, dalam Sitanggang 2014). Ciri penting dari konsumsi adalah bahwa faktor yang mempengaruhi pengeluaran konsumsi rumah tangga baik perorangan maupun keseluruhan adalah pendapatan. Fungsi konsumsi menunjukkan hubungan yang positif antara 
tingkat disposable income dalam perekonomian dengan jumlah konsumsi dimana faktor lain yang mempengaruhi konsumsi dianggap konstan (Sitanggang, 2014). Melihat fenomena di atas, maka peneliti bermaksud untuk mengetahui faktorfaktor makro ekonomi yang mempengaruhi konsumsi, membahas bagaimana kecenderungan mengkonsumsi marjinal dan pola konsumsi masyarakat Jawa Timur.

\section{METODE PENELITIAN}

Penelitian ini dilakukan di Jawa Timurdengan pertimbangan bahwa tingkat konsumsi masyarakat Jawa Timur terus mengalami peningkatan yang cukup singnifikan. Pada tahun 2015 konsumsi rumah tangga meningkat $4,91 \%$ dan pertumbuhan ekonomi sebesar $5,22 \%$ (BPS Jawa Timur, 2016). Data yang digunakan dalam penelitian ini adalah data sekunder secara time series yang diperoleh dari Badan Pusat Statistik (BPS) dan Bank Indonesia (BI), yang meliputi data pengeluaran konsumsi rumah tangga, produk domestik regional bruto (PDRB), inflasi, tingkat suku bunga, dan jumlah penduduk Jawa Timur pada tahun 2001 sampai dengan 2015.

Tujuan pertama yaitu mengetahui faktor-faktor makro ekonomi yang mempengaruhi konsumsi masyarakat Jawa Timur dijawab dengan menggunakan metode regresi linier berganda dengan tingkat signifikansi $\alpha=5 \%$. Persamaan yang digunakan adalah :

$$
Y=\beta 0+\beta 1 X 1+\beta 2 X 2+\beta 3 X 3+\beta 4 X 4+\varepsilon
$$

Dimana $Y$ adalah Konsumsi Masyarakat, X1 adalah pendapatan masyarakat, $\mathrm{X} 2$ adalah Inflasi, X3 adalah tingkat suku bunga, X4 adalah jumlah penduduk, $\beta 0$ adalah konstanta, $\beta 1-\beta 4$ adalah koefisien regresi dan $\varepsilon$ adalah error term.

Tujuan kedua mengenail analisis kecenderungan mengkonsumsi marjinal masyarakat Jawa Timur dijawab dengan menggunakan rumus Marginal Propensity to Consume (MPC).MPC digunakan untuk melihat seberapa besar perubahan konsumsi yang dilakukan masyarakat diakibatkan oleh besarnya perubahan pendapatan.Untuk menghitung besarnya MPC digunakan rumus sebagai berikut :

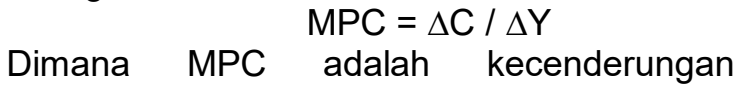
mengkonsumsi marjinal, $\Delta \mathrm{C}$ adalah besarnya perubahan konsumsi, dan $\Delta Y$ adalah besarnya perubahan pendapatan

Sedangkan tujuan yang ketiga yaitu untuk mengetahui pola konsumsi masyarakat Jawa Timur, di jelaskan melalui data pengeluaran dan konsumsi rumah tangga di Jawa Timur yang meliputi data pengeluaran konsumsi per kapita kelompok makanan dan non makanan.Data tersebut diperoleh dari hasil Survei Sosial Ekonomi Nasional (Susenas) Jawa Timur pada tahun 2014 dan 2015.

\section{HASIL DAN PEMBAHASAN}

\section{Faktor yang Mempengaruhi Konsumsi Masyarakat Jawa Timur}

Sebelum dilakukan pengujian regresi linier berganda, variabel independen terlebih dahulu di uji asumsi klasik untuk mengetahui apakah dalam model yang diteliti mengalami penyimpangan klasik atau tidak.Berdasarkan hasil uji asumsi klasik variabel jumlah penduduk dan PDRB tidak bebas multikolinieritas.Peneliti memutuskan untuk membuang variabel jumlah penduduk, dengan asumsi bahwa konsumsi masyarakat sangat dipengaruhi oleh pendapatan. Sehingga variabel independen lainnya (PDRB, inflasi , suku bunga) tidak mengalami penyimpangan klasik.

Berdasarkan hasil uji serentak (Uji F), variabel independen (PDRB, inflasi, suku bunga) mempengaruhi konsumsi dengan nilai sig sebesar $0,00(0,00<0,05)$. Berdasarkan uji parsial (Uji T) variabel PDRB dan tingkat suku bunga mempengaruhi konsumsi, sedangkan variabel inflasi tidak mempengaruhi konsumsi masyarakat.Nilai koefisien untuk variabel PDRB dan tingkat suku bunga masing-masing adalah 0,827 dan 0,334. Hal ini menunjukkan bahwa masyarakat menyumbang kenaikan konsumsi sebesar 0,827 dari PDRB dan 0,334 dari tingkat suku bunga., artinya jika terjadi kenaikan pendapatan dan tingkat suku bunga sebesar $1 \%$ maka konsumsi akan 
meningkat sebesar 0,827 dan 0,334. Inflasi tidak mempengaruhi konsumsi masyarakat Jawa Timur.Hal ini tidak sesuai dengan teori ekonomi yang menyebutkan bahwa apabila terjadi kenaikan harga-harga barang maka akan terjadi inflasi dan akan menyebabkan turunnya konsumsi masyarakat karena turunnya pendapatan. Hal tersebut disebabkan karena tingkat pendapatan penduduk Jawa Timur terus mengalami peningkatan.Adapun model regresi yang dapat di susun berdasarkan temuan analisis ini adalah :

$$
\begin{gathered}
Y=0,431+0,827 \times 1+0,334 X 3 \\
\text { Simulasi model yang dapat }
\end{gathered}
$$
disimpulkan dari persamaan regresi tersebut yaitu, Pertama; tanpa adanya intervensi dari variabel PDRB dan tingkat suku bunga maka konsumsi masyarakat Jawa Timur sebesar Rp. 0.431. Kedua; ketika terjadi peningkatan 1 satuan PDRB maka konsumsi masyarkat Jawa Timur adalah $0,431+(0,827 \times 1)+$ $(0,334 \times 0)=$ Rp. 1,258

\section{Kecenderungan Mengkonsumsi Marjinal Masyarakat Jawa Timur}

Nilai MPCdan APC masyarakat Jawa Timur di hitung menggunakan data konsumsi per kapita per tahun dan Produk Domestik Regional Bruto per kapita per tahun dari tahun 2001 hingga tahun 2015. Perhitungan MPC menggunakan rumus :

$$
\mathrm{MPC}=\frac{\text { Konsumsi tahun } t-\text { konsumsi tahun } t-1}{\text { pendapatan tahunt }- \text { pendapatan tahun } t-1}
$$

Sedangkan , APC $=\mathrm{C} / \mathrm{Y}$

Dimana $C$ adalah konsumsi dan $Y$ adalah pendapatan.

Nilai Marginal Propensity to Consume (MPC) yang menggambarkan adanya perubahan konsumsi akibat perubahan pendapatan dihitung dari konsumsi per kapita dan PDRB per kapita penduduk Jawa Timur. Data hasil perhitungan di sajikan dalam bentuk tabel 2 sebagai berikut :

Tabel 2. Konsumsi, PDRB, MPC dan APC Jawa Timur

\begin{tabular}{ccccc}
\hline Tahun & Konsumsi & Pendapatan & MPC & APC \\
\hline 2001 & 1613328,00 & 5493800,00 & & 0.293663 \\
2002 & 2085504,00 & 6316570,00 & 0.573885776 & 0.330164 \\
2003 & 2145804,00 & 7025920,00 & 0.085007401 & 0.305413 \\
2004 & 2134464,00 & 9400000,00 & -0.004776587 & 0.227071 \\
2005 & 2716452,00 & 11060000,00 & 0.350595181 & 0.245610 \\
2006 & 2930832,00 & 12830000,00 & 0.121118644 & 0.228436 \\
2007 & 3136704,00 & 14500000,00 & 0.123276647 & 0.216324 \\
2008 & 4271316,00 & 16760000,00 & 0.502040708 & 0.254852 \\
2009 & 4437624,00 & 22932308,56 & 0.026944214 & 0.193510 \\
2010 & 4896240,00 & 26371100,00 & 0.133365459 & 0.185667 \\
2011 & 5753880,00 & 29613050,00 & 0.264544487 & 0.194302 \\
2012 & 6290700,00 & 32770380,00 & 0.170023406 & 0.191963 \\
2013 & 7036884,00 & 36035450,00 & 0.228535376 & 0.195277 \\
2014 & 8094960,00 & 39903870,00 & 0.273516319 & 0.202862 \\
2015 & 9965664,00 & 43499208,69 & 0.520313707 & 0.229100 \\
\hline
\end{tabular}

Sumber : Data diolah, 2017

Dari tabel 2 diketahui bahwa nilai MPC Jawa Timur dari tahun 2002 hingga tahun 2015 tidak stabil dan tidak menunjukkan angka yang menurun ketika pendapatan meningkat. Apabila dilihat nilai
MPC tersebut dapat dibagi ke dalam tiga periode.Periode pertama yaitu pada tahun 2002 hingga 2004 MPC Jawa Timur mengalami penurunan.MPC tertinggi yaitu terjadi pada tahun 2002 dimana tingginya 
kecenderungan mengkonsumsi masyarakat tersebut akibat dari tingginya sebagian harga kebutuhan pokok. Tingginya inflasi pada tahun sebelumnya yang mencapai $13,32 \%$ juga mengakibatkan penduduk lebih banyak mengeluarkan pendapatannya untuk konsumsi meskipun pada tahun 2002 inflasi Jawa Timur turun menjadi 9,27\%.

Periode selanjutnya yaitu tahun 2006 hingga 2007 nilai MPC Jawa Timur tetap stabil pada angka 12 persen. Nilai tersebut turun dari tahun 2005, dimana besaran nilai MPC mencapai 0,350 atau $35 \%$, tingginya MPC pada tahun 2005 disebabkan karena terjadinya inflasi yang cukup tinggi di Jawa Timur yaitu sebesar 15,19\%. Kenaikan inflasi tersebut salah satunya adalah dampak dari naiknya harga Bahan Bakar Minyak (BBM) yang dilakukan oleh pemerintah. Sedangkan pada tahun 2006 - 2007 penurunan kecenderungan mengkonsumsi disebabkan karena adanya penurunan inflasi menjadi $6,74 \%$.

Kemudian pada periode ketiga yaitu tahun 2012 hingga 2015 menunjukkan nilai MPC yang terus meningkat.Pada tahun 2012 pengeluaran penduduk mulai bergeser kearah pengeluaran yang lebih besar.Peningkatan pengeluaran tersebut oleh masyarakat digunakan untuk memenuhi kebutuhan non makanan.Tahun 2012 merupakan tahun pertama dimana konsumsi penduduk bergeser untuk memenuhi kebutuhan non makanan. Sebesar 50,52\% pengeluran penduduk di Jawa Timur digunakan untuk konsumsi non makanan, lebih tinggi dari tahun sebelumnya yang hanya sebesar 49,36\%. Kondisi ini terus berlanjut hingga pada tahun 2015 kecenderungan untuk mengkonsumsi penduduk terus meningkat hingga mencapai $52 \%$. Peningkatan tersebut tetap terjadi untuk kelompok non makanan, dimana besarannya menjadi 54,12\% pada tahun 2015 .

Nilai MPC Jawa Timur berkisar antara $-0,004$ - 0,57. Rata-rata nilai MPC Jawa Timur adalah sebesar 24\%. Angka tersebut menunjukkan bahwa 24 persen dari pendapatan penduduk Jawa Timur digunakan untuk konsumsi, sedangkan sisanya $76 \%$ digunakan untuk keperluan diluar konsumsi. Apabila dibandingkan dengan Indonesia, nilai MPC Jawa Timur masih tergolong rendah.Nilai MPC Indonesia besarnya mencapai 0,623 setelah terjadinya krisis ekonomi (Fikri et. al, 2014).Hal ini menunjukkan bahwa tingkat kesejahteraan masyarakat Jawa Timur lebih baik dari pada tingkat kesejahteraan masyarakat Indonesia, sebab persentase dari pendapatan yang digunakan untuk konsumsi lebih sedikit dari pada persentase untuk kebutuhan diluar konsumsi.Tingginya persentase tabungan tersebut tidak terjadi pada semua kalangan disebabkan karena adanya ketimpangan pendapatan.Distribusi pendapatan per kapita penduduk antar kabupaten/kota di Jawa Timur relatif tidak merata.Ketimpangan pendapatan yang terjadi merupakan ketimpangan yang tinggi, dimana setiap tahunnya angka ketimpangan pendapatan penduduk Jawa Timur terus mengalami peningkatan (Iswanto, 2015).Pendapatan perkapita tertinggi penduduk Jawa Timur berada di wilayah yang sudah maju baik dari segi pembangunan dan kecepatan pertumbuhan ekonomi.Wilayah tersebut adalah Kabupaten Gresik, Kota Malang, Kota Madiun dan Kota Surabaya.

Rata-rata nilai APC Jawa Timur adalah sebesar $23 \%$, artinya persentase pendapatan yang digunakan masyarakat untuk konsumsi hanya sebesar $23 \%$. Semakin kecil persentase yang dikeluarkan untuk konsumsi maka dikatakan bahwa tingkat kesejahteraan masyarakat tersebut membaik

\section{Pola Konsumsi Masyarakat Jawa Timur}

Pengukuran kesejahteraan rumah tangga selain dapat dilihat dari jumlah pendapatannya juga dapat dilihat dari pengeluaran konsumsinya. Pengeluaran konsumsi rumah tangga tidak hanya sebatas pangan, namun juga non pangan seperti sandang, papan dan kebutuhan akan jasa. Struktur pengeluaran konsums penduduk Jawa Timur dapat dilihat pada tabel 3 berikut: 
Tabel 3. Pengeluaran Rata-rata per Kapita per Bulan Menurut Jenis Pengeluaran dan Daerah Tempat Tinggal di Jawa Timur Tahun $2014-2015$

\begin{tabular}{lcccccc}
\hline \multirow{2}{*}{$\begin{array}{c}\text { Jenis } \\
\text { Pengeluaran } \\
\text { (Rp) }\end{array}$} & \multicolumn{2}{c}{ Kota } & \multicolumn{2}{c}{ Desa } & \multicolumn{2}{c}{ Kota+Desa } \\
\cline { 2 - 7 } & $\mathbf{2 0 1 4}$ & $\mathbf{2 0 1 5}$ & $\mathbf{2 0 1 4}$ & $\mathbf{2 0 1 5}$ & $\mathbf{2 0 1 4}$ & $\mathbf{2 0 1 5}$ \\
\hline Makanan & 373.805 & 427.218 & 297.531 & 338.325 & 333.944 & 380.993 \\
Persentase (\%) & 45,23 & 41,39 & 55,53 & 52,51 & 49,50 & 45,88 \\
-bahan makanan & 216.067 & 264.195 & 188.566 & 225.206 & 201.695 & 243.920 \\
-makanan \& & 118.445 & 122.251 & 68.837 & 71.559 & 92.520 & 95.891 \\
minuman jadi & 39.293 & 40.772 & 40.128 & 41.560 & 39.729 & 41.182 \\
-rokok & 452.687 & 604.896 & 238.272 & 306.017 & 340.635 & 449.479 \\
Non Makanan & 54,77 & 58,61 & 44,47 & 47,49 & 50,50 & 54,12 \\
Persentase (\%) & $\mathbf{8 2 6 . 4 2 9}$ & $\mathbf{1 . 0 3 2 . 1 1 4}$ & $\mathbf{5 3 5 . 8 0 3}$ & $\mathbf{6 4 4 . 3 4 1}$ & $\mathbf{6 7 4 . 5 8 0}$ & $\mathbf{8 3 0 . 4 7 2}$ \\
\hline Total & & & & & & Sumber:
\end{tabular}

Sumber : Susenas, 2015

Berdasarkan tabel 3 dapat dilihat ratarata pengeluaran per kapita sebulan penduduk Jawa Timur pada tahun 2015 sebesar Rp. 830.427, dimana sekitar 54,12\% dikeluarkan untuk memenuhi kebutuhan konsumsi non makanan sedangkan 45,88\% untuk pengeluaran konsumsi makanan. Membandingkan dengan rata-rata pengeluaran per kapita sebulan pada tahun sebelumnya terlihat bahwa masing-masing kelompok makanan dan non makanan mengalami kenaikan.Kenaikan rata-rata per kapita sebulan pada kelompok makanan sebesar Rp. 47.049 sedangkan kelompok non makanan sebesar Rp. 108.844.Kenaikan yang cukup signifikan pada kelompok non makanan membuktikan adanya pergeseran struktur pengeluaran penduduk yang sebelumnya lebih condong kepada pengeluaran konsumsi makanan bergeser untuk konsumsi non makanan.Hal ini nyata terlihat dari besarnya pengeluaran non makanan dibandingkan dengan makanan.Semakin meningkatnya presentase pengeluaran untuk non makanan ini menunjukkan bahwa kesejahteraan penduduk Jawa Timur semakin membaik.

Pengeluaran untuk makanan didominasi oleh pengeluaran bahan makanan, kemudian bahan makanan dan minuman jadi serta rokok.Sedangkan untuk kelompok non makanan, pengeluaran terbesar yang dibelanjakan oleh penduduk Jawa Timur berasal dari kelompok perumahan dan fasilitas rumah tangga sebesar Rp. 220.045 per kapita sebulan pada tahun 2015.Angka tersebut meningkat dari tahun sebelumnya yang nilainya sebesar Rp. 122.573 per kapita sebulan. Konsumsi untuk non makanan kemudian diikuti oleh kelompok aneka barang dan jasa sebesar Rp. 11.530 per kapita sebulan dan kelompok barang tahan lama sebesar Rp. 54.735 per kapita sebulan.

\section{KESIMPULAN}

\section{Simpulan}

Berdasarkan hasil dan pembahasan yang telah dipaparkan maka dapat disimpulkan bahwa; Variabel makro ekonomi yang mempengaruhi konsumsi Jawa Timur adalah PDRB dan tingkat suku bunga dengan nilai koefisien sebesar 0,827 dan 0,334 . Hal ini menunjukkan bahwa apabila terjadi kenaikan pendapatan dan tingkat suku bunga sebesar 1\% maka konsumsi akan meningkat sebesar 0,827 dan 0,334.Nilai MPC masyarakat Jawa Timur berkisar antara -0,004 - 0,573 dengan rata-rata sebesar 0,240.Apabila dibandingkan dengan Indonesia, MPC Jawa Timur jauh lebih rendah.Rendahnya nilai MPC tersebut menunjukkan bahwa tingkat kesejahteraan masyarakat Jawa Timur lebih baik dari pada tingkat kesejahteraan masyarakat Indonesia.Selama kurun waktu dua tahun dari tahun 2014 - 2015 pola konsumsi masyarakat Jawa Timur menunjukkan pola yang konsumtif. Konsumsi terbesar adalah konsumsi non makanan dengan persentase $54,12 \%$ pada tahun 2015. Tingginya 
persentase pengeluaran untuk non makanan menunjukkan bahwa kesejahteraan masyarakat Jawa Timur semakin membaik.

Saran

Saran yang dapat diberikan oleh peneliti adalah perlu adanya suatu kebijakan yang dapat meningkatkan pendapatan masyarakat, karena konsumsi sangat dipengaruhi oleh pendapatan.Salah satunya adalah memperbanyak lapangan pekerjaan.Pemerintah harus membuat kebijakan pembangunan yang memprioritaskan pada daerah yang tertinggal tanpa mengabaikan daerah yang sudah maju.Sedangkan bagi daerah yang sudah maju perlu kiranya memberikan bantuan bagi daerah yang tertinggal seperti pembiayaan program pemberdayaan masyarakat yang dapat meningkatkan kualitas sumber daya manusia, karena hal ini dapat memberikan dampak yang positif bagi pertumbuhan dan pendapatan bagi masyarakat.

\section{DAFTAR PUSTAKA}

Badan Perencanaan Pembangunan Daerah Provinsi Jawa Timur. 2016. Buku Data Dinamis Provinsi Jawa Timur Semester 12016

Badan Perencanaan Pembangunan Daerah Provinsi Jawa Timur. Buku Data Dinamis Provinsi Jawa Timur Maret 2016

Badan Pusat Statistik Jawa Timur. Produk Domestik Regional Bruto Menurut penggunaan Atas Dasar Harga Berlaku. 2016

Badan Pusat Statistik Jawa Timur. Statistik Daerah Provinsi Jawa Timur 2016.

Badan Pusat Statistik Jawa Timur. Rancangan Awal Rencana Pembangunan Jangka

Menengah Daerah Provinsi Jawa Timur 2104-2019.

Badan Pusat Statistik Jawa Timur. Provinsi Jawa Timur Dalam Angka 2016.
Badan Pusat Statistik. Laporan Eksekutif Pengeluaran dan Konsumsi Rumah Tangga di Jawa Timur 2015

Badan Pusat Statistik. Produk Domestik Regional Bruto per Kapita Atas Dasar Harga Berlaku Menurut Provinsi 2010-2014

Bank Indonesia. 2016. Tingkat Suku Bunga Indonesia.

http://www.bi.go.id/en/moneter/birate/data/Default.aspx, diakses tanggal 1 November 2016.

Bank Indonesia. 2016. Kajian Ekonomi dan Keuangan Regional Provinsi Jawa Timur November 2016.

Data Dinamis Propinsi Jawa Timur Triwulan I. 2016. Badan Perencanaan Pembangunan Daerah Propinsi Jawa Timur. Surabaya

Fikri, M., Amir, A., Achmad, E. 2014. Analisis Konsumsi Masyarakat Indonesia Sebelum dan Sesudah Krisis Ekonomi. Jurnal Perspektif Pembiayaan dan Pembangunan Daerah, Vol 1, No. 3:165-170

Hasil Survei Sosial Ekonomi Nasional Tahun 2001 - 2014 Provinsi Jawa Timur. Badan Pusat Statistik Provinsi Jawa Timur

Iswanto, D. 2015. Ketimpangan Pendapatan antar Kabupaten/Kota dan Pertumbuhan Ekonomi di Jawa Timur. Signifikan. Vol 4, No.1:41-66

Sitanggan. H. 2014. Analisis Faktor-Faktor yang Mempengaruhi Konsumsi di Provinsi Sumatra Utara. Jurnal Tabularasa PPS Unimed. Vol 11. No. 2: $\quad 145-164$

Sukirno, S. 2002. Pengantar Teori Makroekonomi (Edisi Ketiga). PT. Raja Grafindo Persada. Jakarta 